\title{
PRIVILEGES OF LABOR UNIONS IN THE STRUGGLE FOR LIFE
}

\author{
WALTER WHEELER COOK \\ Professor of Law, Yale Üniversity
}

One of the most deplorable effects of the world war is that the attention of the community is of necessity largely diverted from matters of domestic policy which deserve and ordinarily receive careful consideration. In times of peace, for example, a decision of the United States Supreme Court dealing with important phases of the relation between capital and labor arouses wide discussion, not only among lawyers but also among the people at large. Things being as they are, two recent decisions of that court involving these problems have gone comparatively unnoticed by all but members of the legal profession, ${ }^{1}$ and indeed the latter have not given them the attention they deserve and normally would receive. The cases referred to are Hitchman Coal \& Coke Co. v. Mitchell ${ }^{2}$ and Eagle Glass \& Manufacturing Co. v. Rowe, ${ }^{3}$ dealing with alleged attempts of labor unions to "unionize"4 the mines and factories concerned. In the belief that these decisions and-what is of much greater importance-the grounds upon which they are based, ought to receive far wider attention than has thus far been given them, it is proposed to examine them somewhat carefully.

As the two cases are very much alike and substantially the same conclusion was reached in both, only the facts and decision in the case of the Hitchman Coal \& Coke Co. will be given in detail. In order fully to appreciate the scope of the decision in that case, however, it will be necessary to state the facts somewhat at length. They were as follows :

The Hitchman Coal \& Coke Co., the plaintiff, was the owner of a coal mine in West Virginia. The defendants were the chief executive officers of the United Mine Workers of America and of its local

\footnotetext{
${ }^{2}$ See, however, the editorial on Breaking the Labor Truce, NEw REPUBLIC (Dec. 22, 1917) 197.

3 (y17) 38 Sup. Ct. 65 .

(Ig17) 38 Sup. Ct. 80.

In the principal case one of the witnesses for the defense testified as follows:

"There is a difference between unionizing a mine and unionizing the employés in a mine; unionizing the employés is having the men join the organization; unionizing a mine is creating joint relations between the employers and employés; a mine cannot be unionized unless the employer enters into contractual relations with the union; it is not the policy or purpose of the United Mine Workers as an organization to coerce a man into doing a thing against his will; this distinction between unionizing a mine and unionizing the employés of a mine has existed since the organization came about, and this method of unionizing a mine existed in 1906 and 1907." 38 Sup. Ct. $65,79$.
}

[779] 
branches which had "jurisdiction" over the territory within which the plaintiff's mine was situated. The defendants were sued as individuals and as officers. Prior to April I6, I906, the mine was operated as a "union" mine under agreement with the United Mine Workers of America. After being closed because of a strike, the mine was reopened as a "non-union" or, as Mr. Justice Brandeis puts it, a "closed non-union" mine. When the men returned to work they were told orally-quoting now from the statement of Mr. Justice Pitney, who wrote the opinion of the majority of the court in the principal case-

"that they could come back, but not as members of the United Mine Workers of America; that thenceforward the mine would be run nonunion, and the company would deal with each man individually. They assented to this, and returned to work on a non-union basis. Mr. Pickett, the mine superintendent, had charge of employing the men, then and afterwards, and to each one who applied for employment he explained the conditions, which were that while the company paid the wages demanded by the union and as much as anybody else, the mine was run non-union and would continue so to run; that the company would not recognize the United Mine Workers of America; that if any man wanted to become a member of that union he was at liberty to do so; but he could not be a member of it and remain in the employ of the Hitchman Company; that if he worked for the company he would have to work as a non-union man. To this each man employed gave his assent, understanding that while he worked for the company he must keep out of the union."

${ }^{8} 38$ Sup. Ct. 65,68 . The italics are the present writer's.

As the agreements with the men were oral, it is difficult to say just what they were. Mr. Justice Brandeis in the dissenting opinion states the matter as follows :

"Thereafter persons applying for work were required as a condition of obtaining employment to agree that they would not, while in the service of the company, be a member of the union, and if they joined the union would withdraw from the company's employ."

In a note the learned judge adds: "About two months after the restraining order was issued in this case the plaintiff company began the practice of requiring applicants for work to sign employment cards in the following terms:

"I am employed by and work for the Hitchman Coal \& Coke Company with the express understanding that I am not a member of the United Mine Workers of America and will not become so while an employe of the Hitchman Coal \& Coke Company; that the Hitchman Coal \& Coke Company is run nonunion and agrees with me that it will run non-union while I am in its employ. If at any time I am employed by the Hitchman Coal \& Coke Company I want to become connected with the United Mine Workers of America or any affiliated organization, I agree to withdraw from the employment of said company, and agree that while I am in the employ of that company I will not make any efforts amongst its employés to bring about the unionizing of that mine against the company's wish. I have either read the above or heard the same read.'

"Prior to that time, the agreement rested in oral understanding merely, and is sufficiently indicated in the following excerpts from the testimony of the mine superintendent as to what he told the men applying for employment:

"I I also told them that any man who wanted to become a member of the United Mine Workers-that that was his business-but he could not be a member of the United Mine Workers and be affiliated with the United Mine Workers and be under the employ of the Hitchman Coal \& Coke Company, or be under 
The company brought the present suit to enjoin the defendants from efforts which, it alleged, were being made to "unionize" the mine illegally and "without its consent." ${ }^{\circ}$ The suit was brought in the United States Circuit (now District) Court for the Northern District of West Virginia. The District Judge granted a restraining order on the filing of the bill, continued it as a temporary injunction and later refused to modify it. ${ }^{7}$ After a hearing on the merits a decree was entered for a perpetual injunction substantially in the same terms as the original restraining order. ${ }^{8}$ This decree was reversed by a unanimous decision of the Circuit Court of Appeals. ${ }^{9}$ The case then came before the United States Supreme Court on writ of certiorari. That court, speaking through Mr. Justice Pitney, reversed the decree of the Circuit Court of Appeals, modified the decree of the District Court and affirmed it as modified. Mr. Justice Brandeis read a dissenting opinion, in which Mr. Justice Holmes and Mr. Justice Clarke concurred.

The evidence and record in the case were voluminous, filling nearly 8,000 pages. No acts or threats of picketing or of physical violence were proved, and those parts of the injunction issued by the District Court which restrained acts of that character were therefore eliminated by the Supreme Court.

The acts of the defendants on which the decision was based seem to have been as follows:

the jurisdiction of the United Mine Workers; that the mine was run non-union so far as the United Mine Workers of America were concerned.

" $Q$. You mean you made every man understand that while he worked for the Hitchman Company he must keep out of the union?

"A. Yes, sir; or at least they said they understood it."

It is possible to take the view that the oral agreements, as distinguished from the later written contracts, amounted to nothing more than a notice to the men that they would be discharged if they joined the union. This apparently was the view taken of the facts by the Circuit Court of Appeals. (1914) 214 Fed. 685, 7I4-7I5.

'It may not be without interest to note that the bill alleged that the men "agreed not to join the union or to become members of the union and to work for the plaintiff as non-union men." (I909) I72 Fed. 963, 964. The original preliminary injunction was issued on affidavits supporting these allegations and on motion to modify was continued on the assumption of its truthfulness. In his opinion refusing to modify the injunction Dayton, District Judge, said: "They [the men] have contracted ... that they will not join this particular union." I72 Fed. 963, 968. The evidence at the hearing, however, showed merely the situation above described, $i$. e., at most an oral agreement to withdraw from the plaintiffs' employment if the employee joined the union. After the agreements were put into writing, the contract clearly was, not to keep out of the union but merely to withdraw from plaintiff's employment if the employee at any time joined or "wanted to become connected with" the union.

' (1909) I72 Fed. 963.

${ }^{8}$ (I9I2) 202 Fed. 512.

' (IgI4) 214 Fed. 685 . 
About July I, I907, three of the defendants submitted a proposal for the unionization of the mine to the general manager of the plaintiff. This was refused by the board of directors of the plaintiff. In September of the same year another of the defendants was sent by the union to organize all the mines in the district. He spent over a month in the vicinity of plaintiff's mines, interviewing employees of the plaintiff, making abusive remarks concerning the plaintiff's superintendent, and arguing that ultimately the wages paid by the plaintiff would be reduced if the mines were not unionized. He succeeded in getting a number of the plaintiff's employees to agree to join the union, but kept the names of those who had done so secret, probablyalthough this does not appear in the evidence-with the object of being able to call a strike suddenly when he had sufficient names. The decree as approved by the majority of the Supreme Court in substance enjoined the defendants from:

"(I) Interfering or attempting to interfere with plaintiff's employés for the purpose of unionizing plaintiff's mine without its consent, by representing or causing to be represented to any of plaintiff's employés, or to any person who might become an employé of plaintiff, that such person will suffer or is likely to suffer some loss or trouble in continuing in or in entering the employment of plaintiff, by reason of plaintiff not recognizing the union, or because plaintiff runs a non-union mine; (2) Interfering or attempting to interfere with plaintiff's employés for the purpose of unionizing the mine without plaintiff's consent, and in aid of such purpose knowingly and willfully bringing about the breaking by plaintiff's employés of contracts of service known at the time to exist with plaintiff's present and future employés; (3) Knowingly and willfully enticing plaintiff's employés, present or future, to leave plaintiff's service on the ground that plaintiff does not recognize the United Mine Workers of America or runs a non-union mine, etc.; (4) Interfering or attempting to interfere with plaintiff's employés so as knowingly and willfully to bring about the breaking by plaintiff's employés, present and future, of their contracts of service, known to the defendants to exist, and especially from knowingly and willfully enticing such employés, present or future, to leave plaintiff's service without plaintiff's consent; (5) Trespassing on or entering upon the grounds and premises of plaintiff or its mine for the purpose of interfering therewith or hindering or obstructing its business, or with the purpose of compelling or inducing, by threats, intimidation, violent or abusive language, or persuasion, any of plaintiff's employés to refuse or fail to perform their duties as such; and (6) Compelling or inducing or attempting to compel or induce, by threats, intimidation, or abusive or violent language, any of plaintiff's employés to leave its service or fail to refuse to perform their duties as such employés, or compelling or attempting to compel by like means any person desiring to seek employment in plaintiff's mine and works from so accepting employment therein."10

${ }^{10} 38$ Sup. Ct. 65,76 . Mr. Justice Brandeis's statement of the terms of the injunction is not, apparently, identical with that of the majority. His version is given below in a discussion of the scope of the injunction. 
As the jurisdiction of the federal court was based solely upon diversity of citizenship, the decision had to be reached under the law of West Virginia. As that state had no statute which governed the matter, the decision involved a determination of the common law of West Virginia upon the question at issue. ${ }^{11}$ When the facts in the only West Virginia case ${ }^{12}$ cited by Mr. Justice Pitney in support of his views are compared with those in the case in hand, it appears that there was in fact no decision in that state upon which the federal court could rely as a precedent actually in point. Indeed, it seems that there was no case in any state involving facts substantially identical with that before the court. In other words, the court had to "find" the law applicable to a new case. ${ }^{13}$ In spite of this, the opinion of the majority of the court does not reveal that the question for decision is actually a novel one. Following the prevailing fashion in judicial opinions, it proceeds to its conclusions chiefly by a process of deductive reasoning from apparently fixed premises supposed to be established by prior cases. The fact that in the last analysis the decision really turns upon notions of policy entertained-more or less consciously or unconsciously-by the members of the court is thus thrown into the background. Where policy is mentioned, it is rather as a justification for existing law than as a basis for a new rule. Perhaps the reason why judges so often adopt this form of reasoning is that suggested by Mr. Justice Holmes in the following passage from his well-known essay upon Privilege, Malice and Intent:

"Perhaps one of the reasons why judges do not like to discuss questions of policy, or to put a decision in terms upon their views as law-makers, is that the moment you leave the path of merely logical deduction you lose the illusion of certainty which makes legal reasoning seem like mathematics. But the certainty is only an illusion, nevertheless. Views of policy are taught by experience of the interests of life. Those interests are fields of battle. Whatever decisions are made must be against the wishes and opinion of one party, and the distinctions on which they go will be distinctions of degree. ${ }^{34}$

The same learned judge has, however, cautioned us as follows against the dangers involved in this "illusion of mathematical certainty :"

"In numberless instances the law warrants the intentional infliction of temporal damage because it regards it as justified. It is on the question of what shall amount to a justification, and more especially

" "The common law is not a brooding omnipresence in the sky, but the articulate voice of some sovereign or quasi sovereign that can be identified; although some decisions with which I have disagreed seem to me to have forgotten the fact. It is always the law of some state." Mr. Justice Oliver Wendell Holmes, in Southern Pacific Co.v. Jensen (rgry) 37 Sup. Ct. 524, 53I.

12 Thacker Coal Co. v. Burke (I906) 59 W. Va. 253.

${ }^{18}$ Some of the cases supposed to be in point will be discussed later, either in the text or in the notes.

"16 (I894) 8 HaRp. L. REV. I, 7. 
on the nature of the considerations which really determine or ought to determine the answer to that question, that judicial reasoning seems to me often to be inadequate. The true grounds of decision are considerations of policy and of social advantage, and it is vain to suppose that solutions can be attained merely by logic and the general propositions of law which nobody disputes. Propositions as to public policy rarely are unanimously accepted, and still more rarely, if ever, are capable of unanswerable proof. They require a special training to enable any one even to form an intelligent opinion about them. In the early stages of law, at least, they generally are acted on rather as inarticulate instincts than as definite ideas for which a rational defense is ready." 15

"The danger is that such considerations should have their weight .. as unconscious prejudice or half conscious inclination. To measure them justly needs not only the highest powers of a judge and a training which the practice of the law does not insure, but also a freedom from prepossessions which is very hard to attain. It seems to me desirable that the work should be done with express recognition of its nature. The time has gone by when law is only an unconscious embodiment of the common will. It has become a conscious reaction upon itself of organized society knowingly seeking to determine its own destinies."16

When the learned justice from whom we have just quoted says that the question at issue cannot be settled "merely by logic," we must not misunderstand him. The settlement of any legal question must of course be reached by logical processes. The error which the learned writer apparently had in mind consists, at least in some instances, in the assumption without sufficient consideration of certain alleged general principles or broad rules of law and then arguing from them by means of reasoning purely deductive in form. In many cases a more careful examination of the supposed principles or rules will show that they are stated so broadly as to go so far beyond existing decisions that they cannot be regarded as representing existing law, ${ }^{18 a}$ or else they are so vague as to be useless in reaching a conclusion. ${ }^{17}$ In other cases the principles or rules stated may fairly

${ }^{15}$ Dissenting opinion in Vegelahn v. Guntuer (1896) 167 Mass. 92, 105-106.

${ }^{18}$ (I894) 8 HARV. L. REv. I, 9.

${ }^{16}$ Compare the following passage from a discussion by my colleague, Prof. Arthur L. Corbin, in (I9I4) 3 Yale Review N. S. 239:

"The supposed pre-existing rule is a mere assumption of the court. According to Professor Sumner's expressive dictum, you can get out of a major premise all you put into it. The supposed general rule is an inductive conpremion on the part of the judge from preceding individual instances. His clusion on the pase is a new instance which later judges and theorists will use decision of the case is a new instance In all cases the judge must construct his own as the basis of a new induction. In all cases the judger. Who can tell to-day major premise, and this he lawion of laborers may lawfly go in attempting to secure just how far a combination of lases involving these questions cannot be decided merely by constructing a syllogism."

${ }^{17}$ Compare Prof. Jeremiah Smith's discussion of The Use of Maxims in Jurisprudence (1805) 9 HARV. L. REV. I3; and the same learned author's more recent discussion of Surviving Fictions (I9I7-I918) 27 YALE LAw JouRNAL, 147 and 3 I7. 
be regarded as representing existing law accurately, if they are properly interpreted, but as stated they contain ambiguous terms which in the argument that follows are not always used in the same sense. ${ }^{18}$ In both cases the difficulty is not so much in trying to solve the problem "merely by logic," but in trying to solve it by false logic. The best corrective for the first form of error consists in a more carefut analysis of prior cases coupled with a clearer conception of just what the function of judges in deciding cases really is. For the second form of error the only cure is the study of that despised subject "Analytical Jurisprudence," $i . e$., of the terms of art used by the legal profession-such as right, duty, etc.-and of the fundamental conceptions which those terms are supposed to represent.

In criticising the prevailing fashion in judicial opinions it is of course not meant to argue that we ought to give up the attempt to reduce our law to a system and to state it so far as possible in terms of general principles and rules. It is obvious that this must be done if we are to study our law scientifically. It is equally obvious that deductive logic has an indispensable place among methods of legal reasoning. We must, however, be sure that our syllogisms are soundly constructed. This they cannot be if ambiguous terms are used without definition, as they frequently-one may almost say, usually-are, not only in cases of the kind under consideration but in legal reasoning generally. ${ }^{10}$

The foregoing observations have been made at this point for the reason that the opinion of the majority in the principal case seems to the present writer to illustrate in many ways these defects in judicial reasoning and so to leave the careful reader unconvinced of its soundness. The extent to which this criticism is true could be shown fully only by a careful examination of the whole opinion-obviously an impossible undertaking within the space at hand. The analysis of typical portions of the opinion will, it is hoped, serve to illustrate what is meant.

After setting forth the facts of the case, Mr. Justice Pitney argues as follows:

${ }^{18}$ An interesting and instructive example of this is found in a recent Pennsylvania case, discussed by Prof. Wesley N. Hohfeld in (19I7) 27 Yale LAw Journal, 66 under the title of Faulty Analysis in Easement and License Cases.

10 "As our law develops it becomes more and more important to give definiteness to its phraseology; discriminations multiply, new situations and complications of fact arise, and the old outfit of ideas, discriminations, and phrases has to be carefully revised. Law is not so unlike all other subjects of human contemplation that clearness of thought will not help us powerfully in grasping it. If terns in common legal use are used exactly, it is well to know it; if they are used inexactly, it is well to know that, and to remark just how they are used." Prof. James Bradley Thayer, Preliminary Treatise on Evidence (1898) Igo. The italics are the present writer's. 
"What are the legal consequences of the facts that have been detailed?

"(I) That the plaintiff was acting within its lawful rights in employing its men only upon terms of continuing non-membership in the United Mine Workers of America is not open to question. Plaintiff's repeated costly experiences of strikes and other interferences while attempting to 'run union' were a sufficient explanation of its resolve to run 'non-union,' if any were needed. But neither explanation nor justification is needed. Whatever may be the advantages of 'collective bargaining,' it is not bargaining at all, in any just sense, unless it is voluntary on both sides. (2) The same liberty which enables men to form unions, and through the union to enter into agreements with employers willing to agree, entitles other men to remain independent of the union and other employers to agree with them to employ no man who owes any allegiance or obligation to the union. (3) In the latter case, as in the former, the parties are entitled to be protected by the law in the enjoyment of the benefits of any lawful agreement they may make. (4) This court repeatedly has held that the employer is as free to make non-membership in a union a condition of employment, as the working man is free to join the union, and that this is a part of the constitutional rights of personal liberty and private property, not to be taken away even by legislation, unless through some proper exercise of the paramount police power. Adair v. United States, 208 U. S. I6r, I74; Coppage v. Kansas, 236 U. S. I, I4. In the present case, needless to say, there is no act of legislation to which defendants may resort for justification.

"(5) Plaintiff, having in the exercise of its undoubted rights established a working agreement between it and its employés, with the free assent of the latter, is entitled to be protected in the enjoyment of the resulting status, as in any other legal right. (6) That the employment was 'at will,' and terminable by either party at any time, is of no consequence. [Citing and quoting from Truax v. Raich (I9I5) 239 U. S. 33, 38.]

"(7) In short, plaintiff was and is entitled to the good will of its employés, precisely as a merchant is entitled to the good will of his customers although they are under no obligation to continue to deal with him. (8) The value of the relation lies in the reasonable probability that by properly treating its employés, and paying them fair wages, and avoiding reasonable grounds of complaint, it will be able to retain them in its employ, and to fill vacancies occurring from time to time by the employment of other men on the same terms. The pecuniary value of such reasonable probabilities is incalculably great, and is recognized by the law in a variety of relations. . . ${ }^{20}$

"(9) The right of action for persuading an employé to leave his employer is universally recognized-nowhere more clearly than in West Virginia - and it rests upon fundamental principles of general application, not upon the English statute of laborers. Thacker Coal

${ }^{2}$ The learned justice here cited the following cases: Brennan v. United Hatters (1906) 73 N. J. L. 729, 749; Brown v. Honiss (1907) 74 N. J. L. 50I, 5I4, et seq.; Jersey City Printing Co. v. Cassidy (Ig02) 63 N. J. Eq. 759, 767; Walker v. Cronin (1871) I07 Mass. 555, 565-566; Moran v. Dunphy (I901) I77 Mass. 485 , and cases there cited; L. D. Willcutt \& Sons Co. v. Driscoll (Ig08) 200 Mass. IIo, II7, etc. 
Co. v. Burke, 59 W. Va. 253,255 ; Walker v. Cronin, Io7 Mass. 555 , 567; Angle v. Chicago, St. Paul, etc. Railway, I5I U. S. I, I3; Noice, Adm'x v. Brown, 39 N. J. L. 569, 572."21

In the sentence numbered (I), the word right is used obviously as a synonym for the word liberty in the sentence numbered (2). Both mean that the plaintiff had a legal privilege $e^{22}$ or liberty to employ non-union men, i. e., that in the absence of a contract so to do, he was under no duty to the defendants-or any one else-to employ union men; and that the men on their part had privileges to form unions if they saw fit. To this simple proposition all, including the defendants, would assent. It is, however, obvious that such a statement tells us absolutely nothing about the rights of the plaintiff in the narrow or strict sense of the word, $i$. e., when it is used as the correlative of duty. That a privilege may exist without an accompanying right is obvious. Suppose A., owner and possessor of a chattel, tells B. that he may take the chattel if he can do so, but that A. will do all he can to stop B. The permission thus given by A. to B. has as its consequence the destruction of B.'s duty to refrain from taking the chattel and confers upon him the privilege of taking it. It does not, however, give B. a right (in the strict sense) to take it, $i . e$., it does not place A. under a duty to let $B$. take it. A. accordingly commits no legal wrong in resisting B.'s efforts to take it. On the other hand, where an easement of way over a piece of land exists, the one having the easement has not only privileges but also rights. A complete analysis will show, indeed, that he has a complex aggregate of rights, privileges, powers and immunities. ${ }^{23}$ Nothing is of course more com-

${ }^{2} 38$ Sup. Ct. $65,72-73$. The sentences have been numbered by the present writer for convenient reference.

${ }^{2}$ In Prof. Wesley N. Hohfeld's now well known discussion of Some Fundamental Legal Conceptions as Applied in Judicial Reasoning (ro13) 23 YaLE LAW JoURNAL, I6, the following scheme of fundamental jural relations is presented:

\begin{tabular}{|c|c|c|c|c|}
\hline $\begin{array}{c}\text { Jural } \\
\text { Opposites }\end{array}$ & $\left\{\begin{array}{l}\text { right } \\
\text { no-right }\end{array}\right.$ & $\begin{array}{l}\text { privilege } \\
\text { duty }\end{array}$ & $\begin{array}{l}\text { power } \\
\text { disability }\end{array}$ & $\begin{array}{l}\text { immunity } \\
\text { liability }\end{array}$ \\
\hline $\begin{array}{c}\text { Jural } \\
\text { Correlatives }\end{array}$ & $\left\{\begin{array}{l}\text { right } \\
\text { duty }\end{array}\right.$ & $\begin{array}{l}\text { privilege } \\
\text { no-right }\end{array}$ & $\begin{array}{l}\text { power } \\
\text { liability }\end{array}$ & $\begin{array}{l}\text { immunity } \\
\text { disability }\end{array}$ \\
\hline
\end{tabular}

It is reproduced here for the convenience of those readers who may not be familiar with it. The discussion which follows is a concrete application of the conceptions and terminology of that scheme to the opinion of the majority of the court in the case in hand.

${ }^{2}$ In what follows the word privilege will be used in preference to liberty. Which one is used is not of great importance, provided it is given a definite meaning and is used throughout a given discussion in that meaning alone. Compare the discussion of the easement and license cases by Professor Hohfeld already referred to, note $I 8$, supra. The one having the easement, for example, has inter alia a right against the owner of the servient estate that he shall not prevent him from entering upon and crossing the land in the specified way. He 
mon than the failure to distinguish clearly between these two meanings of the word right as ordinarily used. It is plain that one cannot construct a sound argument by slipping unconsciously from one meaning to the other, yet this is just what the learned justice seems to do, for in the sentence numbered (3) he has clearly left the field of legal privileges with their corresponding no-rights and has (apparently without realizing it) passed into that of rights in the strict sense with their corresponding duties. The assertion now is, in essence, that certain persons are under certain duties to refrain from certain acts which will disturb the parties "in the enjoyment of the benefits of any lawful agreement they may make." To this proposition also, if properly interpreted, we shall assent-although it does not, as seems to be supposed by the learned justice, follow from the propositions concerning privileges. However, it must at once be noted that it does not follow that, because some acts of interference with the enjoyment of the benefits of a lawful agreement are unlawful, all acts of interference are necessarily prohibited. Here as elsewhere it is established by the decisions that interferences with the situation resulting from the making of lawful contracts are at times justifiable and lawful. ${ }^{24}$ In other words, the proposition of the learned judge, if it is to be an accurate statement of the law, must be interpreted merely as stating that parties are "entitled to be protected by the law in the enjoyment of the benefits resulting from lawful agreements" only to a limited, not to an unlimited, extent. Thus interpreted, however, the proposition, while true, leaves unsolved the real problem: What forms of interference are forbidden and what are permitted?

In the sentence numbered (4), in the phrase "constitutional rights of personal liberty and private property," the learned justice uses rights in still a third sense. In the cases cited it was held that under the federal constitution there exist certain immunities from governmental power, i. e., that the governments in our system, both federal and state, are under legal (constitutional) disabilities (lack legal power) to make laws which will deprive employers of the privileges

has a power to transfer the easement of way by transferring the estate to which it is appurtenant. He has an immunity from having his rights, privileges and powers destroyed either by the action of the owner of the servient estate or by that of other persons generally.

${ }^{24}$ As an illustration, consider the following single example from a multitude which come to mind. In Pickett $v$. Walsh (1906) 192 Mass. 572,78 N. E. 753 a union of masons struck, $i$. e., combined to refuse to lay bricks, in order to get the work of "pointing" the mortar after the bricks were laid. This necessarily resulted in the discharge of the "pointers," $i$. e., of men who made a specialty of pointing. The "pointers" brought an action to enjoin the masons from carrying out their plan. The action of the masons was held justified on the ground that their object was to secure work for themselves. To the same effect is National Protective Association v. Cumming (I902) I70 N. Y. 315,63 N. E. 369. 
before referred to of employing non-union men if they so choose, or employees of their privileges of working for the employers without joining a union. Right here means, therefore, neither right in the strict sense of a claim against others that they shall act or refrain from acting, nor privilege to act without violation of duty. ${ }^{20}$

In these three sentences, therefore, the learned author of the opinion has, apparently without being conscious of it, dealt with: (I) privilege-"no-right" relations; (2) right-duty relations; (3) immunity-disability relations. Clearly from propositions concerning any one of these, no inferences can be drawn concerning the others by any logical process which is merely deductive, although the existence of one set of relations may in some cases furnish a strong reason for recognizing the existence of the other set as a matter of policy. ${ }^{28}$

If now in the sentence numbered (5) we substitute for the word right the word privilege where clearly that is the meaning, we have the following: "Plaintiff, having in the exercise of its undoubted privileges established a working agreement between it and its employés, is entitled [i.e., has a right in the strict sense] to be protected in the enjoyment of the resulting status, as in any other legal right. . $^{37}$ Here also it is at once obvious that the right (claim) to

${ }^{25}$ In all cases dealing with the constitutionality of legislative action, we are obviously discussing the legal powers and disabilities of governments and the correlative liabilities and immunities of the individual. While it is customary also to speak of the constitutional rights of the individual, the legal relations chiefly involved fall into the "power-liability" and "immunity-disability" groups. Of course if a given law is unconstitutional because of the lack of power to enact it on the part of the governmental body in question, a further consequence is that, for example, certain rights or privileges (or both) of the persons concerned are not abolished with a consequent substitution of "no-rights" and duties in their place. It follows, of course, that as against persons who claim to act for the government in enforcing the supposed law, the persons in the group concerned have rights in the strict sense, giving rise to actions for damages or to actions for specific relief (replevin, injunction, etc.) Here, as in most cases, a complete analysis of the jural relations involved reveals a complex aggregate. Obviously, however, it does not follow by necessary or merely logical inference that the persons thus protected by the constitution have rights (in the strict sense) against persons not acting on behalf of the government, that the latter shall not so act as to deprive them of the benefits of the freedom of action thus guaranteed by the constitution.

${ }^{25}$ The statement in the text must not be misunderstood. When we decide, for example, that as against B., A. has a certain privilege, we of course necessarily ("merely by logic") conclude that $B$. has a "no-right" against A. with reference to the same matter. These statements are merely different ways of saying the same thing. What is meant in the text is simply that we cannot by mere logical inference go from A.'s rights to $A$.'s privileges, etc.

${ }^{27}$ To what does the phrase "any other legal right" refer? To "resulting status"? That can hardly be, for "resulting status" seems to be a name for the state of facts brought about by the making of the lawful agreements of employment. If, on the other hand, it refers back to the word "rights" used at the 
protection of the resulting "status" is a different thing from the privilege to enter into the relations giving rise to the (so-called) status. The existence of the right (claim) has not been proved merely by showing the existence of the privileges to create the "status," i. e., the former cannot be deduced from the latter "merely by [deductive] logic." Sound policy may dictate that the privilege to enter into the relations in question be accompanied by and, so to speak, protected by a right, or rights, not to have the resulting "status" interfered with in certain ways. Whether it does so dictate can be determined only by a discussion of the real questions of policy involved.

So far, therefore, as the learned justice meant to say that the right of the plaintiff to protection necessarily followed as a matter of mere logical inference from the privilege to make the agreements referred to, the reasoning is clearly fallacious. The fallacy of the kind of reasoning here criticized appears clearly if one examines concrete cases. For example, in the recent case of Homan v. Hall ${ }^{28}$ the defendants, for purposes which need not here be stated, induced plaintiff's fiancé to break his engagement with her. It was held that these facts gave the plaintiff no right of action. Clearly, however, on Mr. Justice Pitney's reasoning, plaintiff necessarily had a cause of action. The argument would run: "Plaintiff, having in the exercise of her undoubted rights entered into an engagement to marry with her fiance with the full assent of the latter, is entitled to be protected in the enjoyment of the resulting status as in any other legal right."20

If, on the other hand, all that the learned justice means by the proposition in question is that good policy demands that such a right to protection be given, it is clear that thus far nothing has been proved and that we are at last face to face with the real question at issue: "Against what kinds of acts ought protection as a matter of policy to be given?" It is obvious without discussion that the resulting status cannot be absolutely protected from interference, for otherwise no one could ever offer employment to anyone who was already employed by another. Such acts of interference, however, must necessarily be recognized as lawful where the one offering employment to

opening of the sentence, it means privilege. So interpreted, however, the sentence does not help the argument of the learned judge, for privileges are protected by refusing legal redress when asked for by the person against whom the privilege is asserted, and are not protected, i. e., vindicated, by affirmative action of the court. For the latter a genuine right is necessary.

${ }^{28}$ (1917, Nebr.) 165 N. W. 88I.

$\approx$ The result in the case just cited may perhaps be criticised on the grounds given in the note in (1918) 27 YALE LAW JouRNAL, 704, viz., that the grounds for defendants' actions were not such as to justify them in doing what they did. That other grounds would clearly justify such interference, however, is clear, as the writer of the note points out. 
another's employees does so for the purpose of securing their services for himself. ${ }^{30}$

Returning to our discussion of Mr. Justice Pitney's opinion: In the sentence numbered (6) we are confronted with the proposition that the right to protection referred to is not merely a right that the breach of lawful contracts with employees shall not be induced by the defendants, for it is stated that the fact that the employment is "at will" (i. e., that it is no breach of contract for the employees to leave the plaintiff's employment) "is of no consequence." According to this, the question is not of securing to the employer the benefits of a contract lawfully entered into, but of protecting him from having defendants entice away employees who are privileged to leave at any time. The case cited for this proposition, ${ }^{31}$ however, held simply that a provision in the Arizona constitution requiring an employer of more than five persons to employ not less than eighty per cent American citizens violated the Fourteenth Amendment, in that it deprived the non-citizen employee of the equal protection of the laws. In other words, this case established that an employee, even though employed only "at will," enjoys a constitutional immunity, even though not a citizen, from having destroyed by state action his privilege of working for whom he will. It also held by necessary inference that the employer on his part enjoys a similar immunity so far as the destruction by state action of his privilege of employing non-citizens is concerned. In the course of its opinion the court did, however, utter the dictum that "by the weight of authority, the unjustified interference of third persons is actionable although the employment is at will." 32 Of course it is; if any act is legally "unjustified" is is actionable. But what is unjustified interference? Is all interference unjustified? That is the question at issue. Once more we are confronted with the real problem of the case, but thus far have met with no real discussion of it.

The sentences numbered ( 7 ) and (8) contain assertions which are unsupported either by what has gone before or by the citation of cases in point. At most, they suggest an analogy and present a brief argument for giving to the employer some protection. They do not in any way, however, serve to suggest how far that protection shall go. ${ }^{33}$ In that numbered (9) we are told "the right of action for

\footnotetext{
${ }^{20}$ It is assumed that the employees are not under contract to remain. The authorities on this question are given below in note 43 .

${ }^{81}$ Truax v. Raich (r9r5) 239 U. S. 33, 44, 36 Sup. Ct. 7. Cf. the discussion in note 25 , supra.

2239 U. S. 33,44 .

${ }^{3}$ The analogy to the merchant's right to the good-will of his customers is interesting, but it serves as an example to illustrate that protection from interference is not absolute. By setting up a rival store I may draw away all the merchant's customers and commit no legal wrong. In other words, it is only
} 
persuading an employé to leave his employer is universally recognized -nowhere more clearly than in West Virginia."34 If this broad assertion means that it is always actionable to persuade servants or employees, not bound by contract to remain, to leave an existing employment, its incorrectness seems obvious. Is there authority for the proposition that A. may not entice away B.'s servant by offering him higher wages, provided of course that the servant is not bound by contract to remain? Business men are doing such things every day. Do they thus render themselves liable to damages ?35 Clearly this general statement needs to be qualified so as to read: "The right of action for wrongfully (or unlazefully, or unjustifiably) persuading an employé to leave his employer is universally recognized." So are all the other rights of action for unlawful acts. Putting the matter shortly: either the broad assertion made is untrue, or else it merely states that an unlawful action is actionable. In either case it does not bring the solution of our problem any nearer.

The cases cited in support of the proposition just criticized of course do not uphold it. In Thacker Coal Co. v. Burke $e^{38}$-the only West Virginia case cited-the supreme court of that state decided merely that a declaration which alleged that the enticing of the servants was "wilful, wrongful and malicious" and "without justifiable cause" was not bad on demurrer. The other cases cited-discussed in the note below ${ }^{37}$-all equally fail to establish anything more than that if one without lawful excuse or justification persuades employees to leave their employer, his act is wrongful.

In the passage quoted, therefore, neither by the citation of binding precedents and the logical application of settled rules of law, nor by

from unjustified interference that the merchant is protected, and in the last analysis the decision of that question must necessarily be based upon notions of economic and social policy.

"The italics are the present writer's.

${ }^{55}$ See discussion infra, p. 749 and the authorities cited in note 43 , post.

${ }^{36}$ (I906) 59 W. Va. 253.

${ }^{37}$ Walker v. Cronin (I87I) I07 Mass. 555, covers only cases where the acts are done "unlawfully" and "without justifiable cause." Angle v. Chicago, St. Paul, Ecc. $R y$. (1894) I5I U. S. I, is not at all in point and contains the merest dictum (p. I3) to the effect that "It has been repeatedly held that if one maliciously interferes in a contract between two parties, and induces one of them to break that contract to the injury of the other, the party injured can maintain an action against the wrongdoer." (The italics are the present writer's.) Noice, Adm'x. v. Brozen (1877) 39 N. J. L. 569 was an action on the case for the seduction of the plaintiff's daughter, stated in one count as an enticement of a servant from the employment of the master. The exact form of the declaration is not given but apparently both counts disclosed the real nature of the cause of action, and whatever is said about servants generally seems clearly to be purely by way of dictum. In addition, if the declaration was in the usual form, as presumably it was, it contained words alleging a wrongful enticement. 
an adequate discussion of the social and economic problem involved, is any real progress made toward the solution of the question at issue, viz., Was there any justification or excuse for the defendants' acts, which admittedly were damaging the plaintiff financially by disturbing the relations existing between it and its employees? In effect Mr. Justice Pitney admits this, for in the following paragraph he says: "We turn now to the matters set up by way of justification or excuse for defendant's interference with the situation existing at the defendant's mine." There can of course be no justification or excuse for unlawful acts. Unless, therefore, the learned justice is prepared to say that there can be no justification for acts which interfere with the status resulting from the making of lawful agreements, this is in effect an admission that these acts were not necessarily unlawful simply because they interfered with "the situation at the plaintiff's mine." From what follows it is difficult to say just what view the learned justice did entertain upon the question. At points he seems to argue that there can be no justification, relying apparently upon the argument contained in that portion of the opinion already analyzed. For example, after stating some of the alleged grounds of justification, he says: "It is a sufficient answer, in law, to repeat that plaintiff had a legal and constitutional right to exclude union men from its employ. "ss Here again we find repeated the same confusion of thought already pointed out. Translating this passage into what the present writer believes to be a more accurate terminology, it reads: "It is a sufficient answer in law, to repeat that plaintiff had a legal privilege to exclude union men from its employ and a constitutional immunity from having this privilege abolished." Stated in this way, it is at once obvious that instead of being a "sufficient answer, in law," it is no answer at all, as it tells us absolutely nothing about the rights (in the strict sense) of the plaintiff as against the defendants. ${ }^{39}$

The time-honored and perfectly useless maxim, Sic utere tuo ut alienum non laedas, is brought into play by the learned justice, as follows:

"The familiar maxim, 'Sic utere tuo ut alienum non laedas'literally translated, 'So use your own property as not to injure that of another person,' but by more proper interpretation, 'so as not to injure the rights of another' (Broom's Leg. Max. [8th ed.] 289) -applies to conflicting rights of every description. For example, where two or more persons are entitled to use the same road or passage, each one in using it is under a duty to exercise care not to interfere with its use by the others, or to damage them while they are using it. And a

${ }^{38} 38$ Sup. Ct. 65,73 . The italics are the present writer's.

80 This error is repeated again in the following passage: "it may be worth while to say, in addition: ... [that] plaintiff was in the reasonable exercise of its rights [privileges] in excluding union men from its employ . .." 38 Sup. Ct. 65, 73 . 
most familiar application is the action for enticing an employé, in which it never was a justification that defendant wished to retain for himself the services of the employé. I Black. Com. 429; 3 Id. I42." "*0

Accepting the learned justice's "more proper interpretation" of the maxim, it amounts simply to saying that if you "injure," i. e., violate, another's rights, you commit a legal wrong. One is tempted to quote the remark of Sir Frederic Pollock, made with reference to a similar statement: "We do not need the House of Lords to tell us that whoever unlawfully interferes. with his neighbor commits an unlawful act; we desire to have it made clear what kind of conduct is unlawful and what is not." 41

Attention must in passing be called to the remarkable statement contained in the passage just quoted, to the effect that it "never was a justification (for enticing away an employé) that defendant wished to retain for himself the services of the employé." The authority cited for this is-what? Blackstone. ${ }^{42}$ Now whether this ever was law or not, ${ }^{48}$ it certainly is not the law of to-day and has not been law for a long time, except in cases where the employee is under a legal duty to remain. ${ }^{4}$ If it were the law, it would, as previously pointed

\footnotetext{
${ }^{20} 38$ Sup. Ct. 65,73 .

"Pollock, Torts (Ioth ed., I9I6) 342.

I Bl. Com. $429 ; 3$ id. r42.

While possibly this may once have been the law, it is somewhat difficult to prove it from the cases. Two of the decisions usually relied upon are Hart v. Aldridge (I774) Cowp. 54, and Blake v. Lanyon (I795) 6 T. R. 22I. In Hart v. Aldridge the jury found that the defendant persuaded the employees who were working by the piece to leave unfinished a piece of work which they had begunclearly a breach of contract if, as the court thought, the contract was bilateral. Lord Mansfield, in delivering the opinion of the court, said: "He [the defendant] knowingly enticed him to leave it unfinished." In Blake v. Lanyon the same state of facts existed, the court saying: "A person who contracts with another to do certain work for him is the servant of that other till the work is finished." Many of the cases often cited for the proposition in question relate to the seduction of daughters or the enticing away of minor sons-cases which obviously must be decided on grounds of their own, in spite of the tendency of our law in the past to confuse them with those relating to servants or employees.

"Recent applications of the law laid down in the two cases referred to in note 42 are found in De Francesco v. Barnum (1890) 63 L. T. 514 and Fred Wilkins v. Weaver [1915] 2 Ch. 322, in both of which the defendant enticed the employee away during the period for whicn tne latter had contracted to work for the plaintiff. The latter case seems open to criticism, as it allowed an action although the employment of the servant by the defendant was only after the servant had definitely left the employment of the plaintiff. Admitting that this breach of contract by the servant was actionable, is it justifiable to treat the broken contract as still in existence? Should we not admit the legal power, though not the privilege, of the servant to break such a contractual obligation and that when broken the primary contractual obligation ceases to exist and there takes its place a secondary obligation to pay damages? If so,-and such a rule seems especially sensible as applied to contracts for personal services-
} 
out, be constantly violated by the business community. Moreover, a careful reading of Blackstone will, it is believed, make it clear that he was writing only of the case where the servant was under contract to remain, ${ }^{45}$ whereas Mr. Justice Pitney is applying his language to a situation in which the employees were privileged to leave at any time.

Looking back over the discussion down to this point, we find: (a) that no precedents have been cited which fairly cover the case in hand-enticing away, for the purposes defendants had in view, employees who were not under contract to remain; (b) that no adequate discussion of the social and economic problems involved has been presented. What discussion there is has been merely incidental to an exposition of supposedly established law. Nevertheless the conclusion has somehow already been reached that the acts of the defendants were unlawful.

In the next important passage of the opinion Mr. Justice Pitney stands upon firmer ground. The plaintiff's employees had gone to work on the understanding that the mine was to be run "non-union." With reference to the conduct of the defendants in getting the men secretly to agree to join the union and to remain at work after having so agreed, the learned justice says:

"True, it is suggested that under the existing contract an employe was not called upon to leave plaintiff's employ until he actually joined the union and that the evidence shows only an attempt by Hughes to induce the men to agree to join, but no attempt to induce them to violate their contract by failing to withdraw from plaintiff's employment after actually joining. But in a court of equity, which looks to the substance and essence of things and disregards matters of form and technical nicety, it is sufficient to say that to induce men to agree to join is but a mode of inducing them to join, and that when defendants 'had sixty men who had signed up or agreed to join the organization at Hitchman,' and were 'going to shut the mine down as soon as they got a few more men,' the sixty were for practical pur-

the defendant did not in any way induce a breach of contract by the servant. That can be argued only if we assume that after the breach by the servant the primary obligation of the contract still existed. The present writer has seen a reference to a note in The Law Journal (London) of February 23, 1918, referring to a recent decision in the Winchester County Court in the case of Best $v$. Place "reported in our current County Courts Reporter Supplement, p. I2" where substantial damages were given against a defendant who enticed a servant (a farm laborer and expert thatcher) to leave his employer without notice, although the employment was only by the week. Here again, however, there was a breach of contract induced by the defendant.

The modern law on the subject is laid down by Lord Kenyon in Nichols $v$. Martyr (I799) 2 Esp. 73I: "To induce a servant to leave his master's service at the expiration of the time for which the servant had hired himself, although the servant had no intention at the time of quitting his master's services [is] not the subject of an action." This was followed in Boston Glass Manufactory v. Binney (I827, Mass.) 4 Pick. 425.

${ }^{5}$ See the passages cited in note 42 , supra. 
poses, and therefore in the sight of equity, already members of the union, and it needed no formal ritual or taking of an oath to constitute them such; their uniting with the union in the plan to subvert the system of employment at the Hitchman mine, to which they had voluntarily agreed and upon which their employer and their fellow employés were relying, was sufficient." ${ }^{46}$

To this Mr. Justice Brandeis in the dissenting opinion replies that there could be no breach of this contract by the men until they had formally joined the union. ${ }^{47}$ Here obviously two views of the fair meaning of the language of the agreement are possible. ${ }^{48}$ Much may be said in favor of that of the majority of the court, when we consider the surrounding circumstances. ${ }^{49}$ Assuming that meaning to be the correct one, the defendants clearly were guilty of inducing repeated breaches of contract by the employees for which no adequate remedy at law existed..$^{50}$ So far, then, as the injunction granted is supported by this part of the opinion, it seems to be in accordance with what may be regarded as settled legal principles. ${ }^{51}$

This brings us to a consideration of the remarkable scope of the injunction as approved by the Supreme Court. The decree contained the usual injunction against threats, intimidation, force or violence,

${ }^{48} 38$ Sup. Ct. 65,74 .

${ }^{17} 38$ Sup. Ct. 65,80 .

${ }^{4}$ See note 5, supra.

40 The real object of the agreement seems to have been to exclude from the plaintiff's employment men affiliated with the union. It is clear that one pledged to join the union falls within the class the employer intended to exclude, and the language of the oral agreement is at least susceptible of the interpretation given it by Mr. Justice Pitney.

${ }^{50}$ It would be difficult, indeed impossible, to say what the pecuniary loss would be. Probably only nominal damages could be had at law for the breach of contract by each employee; yet from plaintiff's point of view the actual injury resulting from having in its employ a large number of union men would be very serious.

${ }^{81}$ To explain what the present writer means by "settled legal principles" would require an essay by itself, so no attempt has been made to do so in detail. The question has to do with the degree of difference between the state of facts before the court and states of fact passed upon in previous decisions. If this difference be sufficiently great, the case cannot fairly be regarded as covered by the previous cases. If on the other hand the difference is sufficiently small, so that no reason of policy can fairly be said to exist for differentiating the present situation from those previously passed upon, we may fairly regard the case in hand as governed by "settled legal principles." The chief practical difference is, that in the one case the court has for the first time to pass upon the policy of a decision one way or the other, while in the other it has previous determinations as to the policy to rely upon. Inasmuch, however, as the court may in any case refuse to follow the past adjudications, ultimately the function of the court in both cases is the same. Cf. "The Dead Hand of the Common Law," (1918) 27 YALE LAW JourNax, 668, discussing the case of Rosen v. United States (1918) 38 Sup. Ct. I48, in which the court refused to follow the "settled legal principles" established by the earlier cases. 
against picketing, and against inducing breaches of employee's contracts or trespassing upon plaintiff's property. As previously stated, the portions which enjoined picketing and acts of physical violence were eliminated by the Supreme Court, as no acts or threats of acts of that character had been shown. The portions of the decree which were approved, however, not only deserve but demand detailed consideration.

One paragraph enjoins the defendants from

"representing ['for the purpose of unionizing plaintiff's mine without plaintiff's consent'] . . . to any of plaintiff's employés or to any person who might become an employe of plaintiff, that such person ... is likely to suffer some loss or trouble in continuing in or in entering the employment of plaintiff, ... representing ... to such employé . . . that such loss or trouble. . . may come by reason of plaintiff not recognizing the United Mine Workers of America, or because plaintiff runs a non-union mine."52

This, be it noted, does not merely protect the "status" resulting from the making of "lawful agreements" by the plaintiff with its employees. Defendants are not to make the forbidden representations to "any person who might become an employe of the plaintiff." Apparently this portion of the injunction is based upon the notion expounded by some judges that employers have a "right to a free flow of labor." ${ }^{3}$ In the whole opinion of the majority of the court there is no discussion of the "free flow of labor" doctrine, and no attempt to justify any such sweeping prohibition. Noteworthy also is the character of the prohibited representations. The defendants are not to represent "that such person . . . is likely to suffer some loss or trouble in continuing in or in entering the employment of plaintiff,

82 The present writer is following here the statement of the form of the injunction as given in the dissenting opinion of $\mathrm{Mr}$. Justice Brandeis. It should be compared with the statement of Mr. Justice Pitney, supra, p. 782, as there are some differences in detail. The italics here and in the following paragraphs are the present writer's.

${ }^{3}$ Two of the leading cases setting forth the doctrine of the employer's right to a "free flow of labor" are Jersey City Printing Co. v. Cassidy (I902) 63 N. J. Eq. 759, and L. D. Willcutt \& Sons Co. v. Driscoll (Ig08) 200 Mass. IIo. It is not always clearly recognized that this general, or generic, form of statement does not enable us to decide a given case raising a novel set of facts. There is clearly no right of an employer to an absolutely free flow of labor, for if there were, no modern labor union could exist for any length of time. Loring, J., in the recent case of Haverhill Strand Theater v. Gillen (I918, Mass.) II8 N. E. 67I, puts the doctrine as follows: "The right to the free flow of labor is not an absolute right; it is limited by the right [privilege] of employees to combine for purposes which in the eye of the law justify interference with the plaintiff's right to a free flow of labor." This is an accurate statement except for the last few words. The law does not justify an "interference with a right." It does justify interferences with certain states of fact and thereby settles that the rights of the plaintiff are not as extensive as he claims. 
... by reason of plaintiff not recognizing the United Mine Workers of America, or because plaintiff runs a non-union mine." Apparently statements to persons contemplating, or who might at any time in the future contemplate, entering plaintiff's employment, to the effect that they were likely to lose financially in the long run and have "some trouble" because of the non-union character of the plaintiff's mine, would be forbidden if made "for the purpose of unionizing plaintiff's mine without its consent." If we are to judge from the decree and not merely from the opinion, it is clear that the court is holding that almost any acts of labor unions done for the purpose of unionizing an employer's business without his consent, are illegal, even where the members of the union are not and never have been employees of the employer concerned. That this is the actual scope of the decision will appear more clearly as we examine the other portions of the injunction.

Another paragraph of the injunction enjoins the defendants from ". . knowingly and willfully enticing ['for the purpose of unionizing plaintiff's mine, without plaintiff's consent'] plaintiff's employés present or future ... to leave plaintiff's service, giving or assigning ... as a reason ... for leaving of plaintiff's service, that plaintiff does not recognize the United Mine Workers of America, or that plaintiff runs a non-union mine."

This prevents the labor union from peacefully inducing employees to exercise their legal privileges (given them by their contract of employment) to leave their employment at any time-always, of course, provided that the union in inducing them to leave is acting "for the purpose of unionizing" the plaintiff's business without his consent. The forms of persuasion forbidden here seem to include peaceful argument that employees ought not to remain at work for an employer who manages a non-union mine. This portion of the injunction is based upon the first part of Mr. Justice Pitney's argument which is analyzed in detail above. As was pointed out, the opinion was not in any way a demonsiration that all acts of this character are illegal.

Another sweeping prohibition is contained in that portion of the decree which enjoins the defendants from " . . knowingly and willfully enticing plaintiff's employés, present or future ... to leave plaintiff's service without plaintiff's consent, against plaintiff's will and to plaintiff's injury."

This of course merely strengthens the protection given to the "status" created by the plaintiff's exercise of his privilege to employ non-union men. It effectually prevents the union from using any means, however peaceful, to induce employees to leave a non-union. employer, even though thereby no breaches of contract are brought about. It is sought to lend additional strength to this stringent prohibition by adding that defendants are enjoined from 
". . . interfering in any manner whatsoever, either by . . persuasion or entreaty, with any person in the employ of plaintiff who hąs contracted with and is in the actual service of plaintiff to ... induce him to quit the service of plaintiff ... or assisting or abetting in any manner his doing so."

To sum up: The injunction prohibits in substance the following conduct on the part of the defendants :

(I) Inducing plaintiff's employees to break their contracts of service;

(2) Inducing by any means plaintiff's employees to leave, even though by their contracts of employment they are privileged to leave at any time;

(3) Persuading persons "who might become employees" of the plaintiff not to do so, by representing to them that they are "likely to suffer some loss or trouble" if they do, because of the non-union character of plaintiff's mine.

The first part seems justified under existing precedents and would probably be regarded by nearly every one as in accord with sound policy. But, be it noted, as applied to this case it would merely prevent the union from inducing plaintiff's employees to remain at work after they had joined the union. To induce them to leave the plaintiff's service after they had joined the union would be merely to induce them to keep, not to break, their contracts.

The remaining portions of the injunction taken as a whole seem to go far beyond any existing precedents in placing upon the activities of labor unions limitations which ought to be imposed only after the most careful consideration of the results of so doing. Mr. Justice Pitney seeks at one point to justify these limitations in a general way by the statement that "the defendants' acts cannot be justified by any analogy to competition in trade. They are not competitors in trade."

The reply to this was given long ago by Mr. Justice Holmes, as follows:

"I have seen the suggestion made that the conflict between employers and employed is not competition. But I venture to assume that none of my brethren would rely on that suggestion. If the policy on which our law is founded is too narrowly expressed in the term free competition, we may substitute free struggle for life. Certainly the policy is not limited to struggles between persons of the same class competing for the same end. It applies to all conflicts of temporal interests." ${ }^{\prime 54}$

The real question therefore in each new case always is as to the limits to be placed upon each of the parties in the "free struggle for life." Where the situation involved is a novel one, this is, of course, purely a problem of economic and social policy, conceal it how we will.

\footnotetext{
${ }^{8}$ Dissenting opinion in Vegelahn v. Guntner (1896) 167 Mass. 92, 107.
} 
In another portion of the opinion, for the detailed discussion of which space is lacking, Mr. Justice Pitney places much emphasis upon alleged acts of "misrepresentation, deceptive statements, and threats of pecuniary loss" made to persons who were not yet but who might become employees of the plaintiff. Assuming the truth of the allegations as to these acts-and there was much evidence to support them-we may well hold such methods of carrying on the economic struggle between employer and employee unjustifiable and so enjoin them. It does not follow that other.methods not involving these things are illegal and should also be enjoined. It should also be noted that "threats of pecuniary loss" seems to imply something quite different from and more serious than the thing enjoined, viz., "representing ... that such person will suffer or is likely to suffer some loss or trouble in . . . entering the employment of plaintiff by reason of plaintiff not recognizing the union, or because plaintiff runs a nonunion mine." This includes far more, apparently, than threats of (i. e., threats to inflict) pecuniary loss.

In the last analysis the decision in a novel situation such as that presented in the principal case must turn upon the notions of policy which the judges who are deciding the case may entertain. Although the present writer has rather definite convictions that in the principal case the minority are more nearly right upon most points than the majority, it is not his purpose to undertake to answer these questions of policy at the present time. His sole object is to show how inadequately the real point at issue is dealt with in the opinion of the majority and to suggest that the policy of the decision must be re-examined before it can be accepted as sound law. Whether our courts will show themselves competent to settle rightly the questions of policy involved is perhaps doubtful. If not, we have our legislative bodies to fall back upon. In making our decision, we shall have to bear in mind that if we do not give organized labor a fair chance to assert itself in competition with organized capital in this "free struggle for life," the only alternative will be a larger and larger measure of direct governmental interference in fixing wages and conditions of employment.55 On the other hand if we do give to the unions the free hand they ask, we may find it necessary by statute to surround them with legal regulations as to conditions of membership,

\footnotetext{
s This of course is what has been going on in Australia. See The Judicial Regulation of Industrial Conditions by W. Jethro Brown (IgI8) 27 YALE IAW JouRnal, 427. Minimum wage laws, the Adamson Law, and similar legislation suggest the possibility of greater developments along this line in our own country. Undoubtedly the experiences we are now going through in the great war will have much effect upon our notions of what it is feasible for the government to undertake in the way of the regulation of matters heretofore regarded as "private" and exempt from governmental interference. The recent program of the British Labor Party is perhaps another sign of the times.
} 
etc., which may not be altogether acceptable. ${ }^{58}$ Which method will in the long run prove most conducive to the welfare of the community is, as stated above, a question with the answer to which the present writer is not at this time primarily concerned.

"What I mean to suggest is that it may be that if we are to give the unions as free $a$ hand as the minority in the case before us are willing to grant them, we shall need to regulate by statute the conditions of admission to the union and of exclusion from it. It seems clear that we cannot permit the unions to acquire a substantial monopoly of furnishing labor in a given line without at the same time providing by legal regulation of some kind that the union is open on fair terms to all alike. To do otherwise would in the end result in state recognition of the power of voluntary associations of workers to exclude from working at their trade reputable workmen who might for some unsubstantial reason be refused admission to the union. In discussions of the whole question this has too often been overlooked, or at least regarded as of slight importance. 